ARGIPA. 2019. Vol. 4, No. 2: 94-106

Available online: https://journal.uhamka.ac.id/index.php/argipa

p-ISSN 2502-2938; e-ISSN 2579-888X

DOI 10.22236/argipa.v4i2.4037

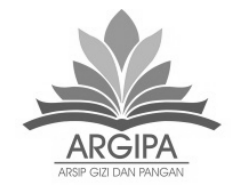

\title{
PEMANFAATAN TEPUNG PISANG KEPOK PUTIH DAN TEPUNG KACANG HIJAU DALAM PEMBUATAN CRISPY COOKIES SEBAGAI SNACK SUMBER SERAT DAN RENDAH NATRIUM
}

\section{Utilization of white kepok banana and mung bean flour in the making of crispy cookies as a fiber source and low potassium snack}

\author{
Rahma Agniya Nugraha \\ Persatuan Ahli Gizi Indonesia \\ Email korespondensi: rahmagniya@gmail.com
}

\begin{abstract}
ABSTRAK
Pola konsumsi masyarakat yang cenderung senang mengonsumsi makanan tinggi kalori, tinggi lemak, tinggi natrium, dan rendah serat dapat menjadi pemicu kejadian hipertensi. Pisang kepok putih dan kacang hijau merupakan pangan lokal yang banyak dibudidayakan di Indonesia dan bahan yang potensial dalam pembuatan snack sumber serat dan rendah natrium bagi penderita hipertensi. Tujuan penelitian ini adalah melakukan pemanfaatan tepung pisang kepok putih dan tepung kacang hijau dalam pembuatan crispy cookies sumber serat dan rendah natrium. Penelitian ini menggunakan rancangan acak lengkap (RAL). Terdapat 3 taraf perlakuan penggunaan tepung pisang kepok putih dan tepung kacang hijau (tanpa terigu), dengan perbandingan 1:9, 2:8, $3: 7$ dan tepung terigu 100\% sebagai kontrol. Analisis data menggunakan uji Anova, bila $p$-value $<0,05$ dilanjutkan dengan uji Duncan. Hasil uji sidik ragam pada uji mutu hedonik menunjukkan bahwa tidak ada perbedaan yang nyata penggunaan tepung pisang kepok putih dan tepung kacang hijau terhadap mutu aroma, rasa, dan tekstur crispy cookies. Hasil uji sidik ragam pada uji hedonik menunjukkan bahwa tidak ada perbedaan yang nyata penggunaan tepung pisang kepok putih dan tepung kacang hijau terhadap aroma dan rasa, namun terdapat perbedaan pada tekstur crispy cookies. Berdasarkan penilaian uji organoleptik didapatkan produk crispy cookies terpilih yaitu F2 dengan perbandingan penggunaan tepung pisang kepok dan tepung kacang hijau 2: 8. Produk crispy cookies terpilih dalam 100 gram mengandung energi 401,8 kkal, protein 18,7 g, lemak 9,2 g, karbohidrat $61 \mathrm{~g}$, serat 6,8 g dan natrium 137,7 mg.
\end{abstract}

Kata Kunci: Crispy Cookies, Hipertensi, Tepung Kacang Hijau, Tepung Pisang Kepok Putih

\section{ABSTRACT}

Consumption patterns of people who tend to enjoy eating foods high in calories, fat, sodium, and low in fiber can be a trigger for hypertension. White kepok bananas and mung beans are local food, widely cultivated in Indonesia, and become a potential ingredient in making fiber and low-sodium snacks for hypertensive sufferers. The purpose of this study was to utilize white kepok banana flour and mung bean flour in making crispy cookies as source of fiber and low sodium. This study used a completely randomized design (CRD). There were 3 levels of treatment using white kepok banana flour and mung bean flour (without wheat flour), namely in the ratio of 1: 9, 2: 8, 3: 7, and 100\% of wheat flour as control. Data was analyzed using the ANOVA test, if the $p$-value $<0.05$ followed by Duncan test. Variance test results on the hedonic quality test showed that there was no significant difference in the use of white kepok banana flour and mung bean flour on the quality of the aroma, taste, and texture of crispy cookies. Variance test results on the hedonic test showed that there was no real difference in the 
use of white kepok banana flour and mung bean flour on the aroma and taste, but there was difference in the texture of crispy cookies. Based on the organoleptic test evaluation, it was obtained that the selected crispy cookies product is F2 by comparing the use of Kepok banana flour and mung bean flour 2:8. Crispy cookies selected in 100 grams contain 401.8 kcal energy, 18.7 gram protein, 9.2 gram fat, 61 gram carbohydrate, 6.8 gram fiber, and $137.7 \mathrm{mg}$ sodium.

Keywords: Crispy Cookies, Hypertension, Mung Bean Flour, White Kepok Banana Flour

\section{PENDAHULUAN}

Hipertensi (tekanan darah tinggi) merupakan masalah kesehatan yang serius karena dapat mengakibatkan kematian. WHO menyebutkan sekitar 9,4 juta orang di dunia meninggal akibat hipertensi dan komplikasi (WHO, 2013). Sementara di Indonesia, berdasarkan data Sample Registration System (SRS) Indonesia tahun 2016, hipertensi dengan komplikasi $(5,8 \%)$ merupakan penyebab kematian nomor 4 (empat) pada semua umur (Usman, et al., 2019).

Data WHO 2015 menunjukkan sekitar 1,13 milyar orang di dunia menderita hipertensi dan terus meningkat sehingga diperkirakan pada tahun 2025 akan ada 1,5 milyar orang yang terkena hipertensi (WHO, 2015). Data Riskesdas tahun 2018 menunjukkan bahwa prevalensi penderita hipertensi usia $\geq 18$ tahun mengalami peningkatan dibanding tahun 2013, yaitu dari 25,8 persen menjadi 34,1 persen (Kemenkes, 2019).

Saat ini, kecenderungan masyarakat mengonsumsi junk food dan gaya hidup yang moderen menjadi salah satu pemicu sepertiga penduduk Indonesia menderita hipertensi. Menurut Sudarmoko (2015), gaya hidup yang tidak sehat, terutama pola makan yang salah merupakan faktor penyebab kekambuhan hipertensi. Makan yang salah dapat meliputi pola konsumsi makanan yang tinggi kalori, tinggi lemak, tinggi natrium, dan rendah serat (Sumarni, et al., 2015).

Pisang kepok putih merupakan pangan lokal yang mudah diperoleh di Indonesia, namun keberadaannya belum populer di masyarakat. Rasa pisang kepok putih yang cenderung kurang manis seringkali dijadikan sebagai pakan burung dibandingkan untuk dikonsumsi. Padahal, pisang kepok putih merupakan pangan yang kaya akan zat gizi, seperti protein 3,1\%, lemak 0,27\%, karbohidrat 83,66\%, dan serat kasar 4,705\% (Patola, et al., 2017). Pisang kepok putih juga mengandung pati yang tinggi sehingga dapat diolah menjadi tepung sebagai bahan dasar aneka cookies dan cake serta merupakan bahan makanan bebas natrium (0 mg/100 gram) (Kusumaningrum dan Rahayu, 2018).

Begitu pula dengan kacang hijau yang keberadaannya tersebar luas di Indonesia. Produksi kacang hijau di Indonesia tahun 2018 mencapai 234,718 ton (Kementan, 2018). Kacang hijau sebagai sumber protein nabati merupakan jenis pangan yang cukup diminati masyarakat Indonesia karena selain mudah diperoleh, harganya juga relatif lebih murah dibandingkan dengan bahan pangan hewani. Dalam 
100 gram kacang hijau kering terkandung 22,9 gram protein, 1,5 gram lemak, 56,8 gram karbohidrat, 7,5 gram serat, dan $42 \mathrm{mg}$ natrium (TKPI, 2017).

Produk cookies merupakan salah satu jenis makanan yang diminati masyarakat. Sifat cookies yang mudah dikonsumsi menjadikannya sebagai makanan selingan yang cocok untuk mengatasi pola hidup masyarakat moderen dengan tingginya tingkat kesibukan. Selain itu, keunggulan produk cookies lainnya adalah daya simpannya yang relatif panjang dan dapat menjadi alternatif pemenuhan gizi bagi penderita hipertensi (Lesmana dan Utari, 2013.) Salah satu jenis cookies yang cukup populer adalah crispy almond cookies. Hal ini karena teksturnya yang renyah dan rasanya yang manis serta gurih menjadikannya primadona baik di kalangan remaja maupun dewasa (Kusuma, et al., 2017).

Produk crispy almond cookies menggunakan tepung terigu sebagai bahan bakunya. Tepung terigu merupakan bahan makanan yang terbuat dari gandum. Pada Juni 2018, terjadi peningkatan impor gandum sebesar $4 \%$ dibandingkan tahun sebelumnya. Menurut Asosiasi Produsen Tepung Terigu Indonesia (Aptindo) dalam Kontan.co.id (2018), kenaikan angka impor gandum dipengaruhi oleh konsumsi tepung terigu masyarakat yang juga meningkat. Selain itu, penggunaan gandum untuk tepung terigu pun cukup besar, yaitu dari 5,67 juta ton yang diimpor, sebanyak 4,4 juta ton digunakan untuk tepung terigu. Oleh karena itu, perlu adanya pemanfaatan sumber daya lokal seperti pisang kepok dan kacang hijau untuk mengurangi angka impor komoditas gandum yang meningkat selama ini.

\section{METODE}

Penelitian ini dilakukan pada bulan April hingga Oktober tahun 2019. Pembuatan tepung pisang kepok putih, tepung kacang hijau, dan crispy cookies dilakukan di kawasan Depok. Analisis proksimat, kadar serat, dan natrium tepung kacang hijau dilakukan di Laboratorium Balai Besar Penelitian dan Pengembangan Pascapanen Pertanian, Bogor. Uji organoleptik dilakukan di Ruang PSG, Universitas Muhammadiyah Prof. DR. HAMKA. Analisis proksimat, kadar serat, dan natrium crispy cookies terpilih dilakukan di Laboratorium Saraswanti Indo Genetech, Bogor.

Tahap pertama penelitian ini adalah pembuatan tepung pisang kepok putih dan tepung kacang hijau. Proses pembuatan tepung pisang kepok putih dilakukan berdasarkan penelitian Kusumaningrum dan Rahayu (2018). Pisang kepok yang dipilih berkarakteristik agak matang (mengkal). Dalam pembuatan tepung pisang kepok, pisang terlebih dahulu dikukus selama 15 menit pada suhu \pm $85{ }^{\circ} \mathrm{C}$. Pengukusan bertujuan untuk menonaktifkan enzim polifenolase yaitu enzim yang menyebabkan adanya browning (pencoklatan) pada 
pisang. Setelah itu, kulit pisang dikupas dan pisang diiris dengan ketebalan $\pm 0,5 \mathrm{~cm}$, kemudian pisang dikeringkan dengan oven bersuhu 60 ${ }^{0} \mathrm{C}$ selama 5 jam. Hasil pisang yang telah kering lalu digiling dengan blender hingga halus dan diayak dengan ayakan ukuran 100 mesh.

Proses pembuatan tepung kacang hijau diawali dengan pemilihan kacang hijau yang sudah dikupas kulit arinya. Setelah itu, kacang hijau disortasi dan dicuci dengan air mengalir. Kacang hijau kemudian ditiriskan selama 2 jam lalu disangrai dengan suhu $\pm 60{ }^{\circ} \mathrm{C}$ selama 25 menit. Biji kacang hijau yang sudah kering kemudian digiling menggunakan blender dan diayak dengan ayakan 100 mesh.

Tahap kedua penelitian ini adalah menentukan formulasi crispy cookies sumber serat dan rendah natrium dengan pemanfaatan tepung pisang kepok putih dan tepung kacang hijau, serta dilakukan uji organoleptik oleh panelis semi terlatih. Adapun parameter yang diamati adalah aroma, rasa, dan tekstur. Rencana formulasi crispy cookies tepung pisang kepok putih dan tepung kacang hijau dapat dilihat pada Tabel 1, kemudian crispy cookies dibuat dan dilakukan uji hedonik dan mutu hedonik.

Uji hedonik dilakukan untuk mengetahui tingkat kesukaan atau kelayakan suatu produk agar dapat diterima oleh panelis (konsumen) berdasarkan 4 tingkatan skala yakni tidak suka, agak suka, suka, sangat suka. Uji mutu hedonik dilakukan untuk mengetahui penilaian panelis terhadap produk crispy cookies pada aspek aroma, rasa, dan tekstur berdasarkan 4 tingkatan skala, yakni penilaian rasa meliputi sangat tidak manis, tidak manis, agak manis, dan manis. Penilaian aroma meliputi langu, agak langu, agak harum, dan harum. Penilaian tekstur meliputi tidak renyah, agak renyah, renyah, dan sangat renyah. Uji ini dilakukan oleh 30 orang panelis semi terlatih.

Tabel 1.

Formulasi crispy cookies

\begin{tabular}{lcccc}
\hline \multirow{2}{*}{ Bahan } & \multicolumn{4}{c}{ Berat (gram) } \\
\cline { 2 - 5 } & F0 & F1 & F2 & F3 \\
\hline Tepung terigu & 100 & 0 & 0 & 0 \\
Tepung pisang kepok putih & 0 & 10 & 20 & 30 \\
Tepung kacang hijau & 0 & 90 & 80 & 70 \\
Maizena & 10 & 10 & 10 & 10 \\
Gula halus & 30 & 30 & 30 & 30 \\
Kuning telur & 20 & 20 & 20 & 20 \\
Putih telur & 80 & 80 & 80 & 80 \\
Santan & 50 & 50 & 50 & 50 \\
Susu skim bubuk & 40 & 40 & 40 & 40 \\
Coklat meises & 20 & 20 & 20 & 20 \\
\hline
\end{tabular}


Formula terpilih berdasarkan uji hedonik dan mutu hedonik diuji secara kimia, meliputi analisis proksimat: kadar air (SNI 2973 -2011 butir A.3), kadar abu (SNI 01-2891-1992, 6.1), kadar protein metode mikro kjeldahl (18-8-31/MU/SMM - SIG), dan kadar lemak metode Weilbull (18-85/MU/SMM - SIG). Selain itu, dilakukan analisis serat (18-8-62/MU/SMM-SIG) dan natrium (18-131/MU/SMM-SIG (ICP OES)).

Rancangan percobaan pada penelitian ini yaitu Rancangan Acak Lengkap (RAL) dengan 2 kali ulangan. Model linier adiktif yang digunakan pada rancangan percobaan tersebut:

$$
Y \mathbf{i j}=\mathbf{\mu}+\tau \mathbf{i}+\varepsilon \mathbf{i j}
$$

Keterangan:

$Y_{i j}=$ Peubah respon crispy cookies karena pengaruh formula crispy cookies perlakuan ke-i dengan ulangan ke-j

$\mathrm{M}=$ Nilai rataan umum

$\mathrm{ti}=$ Pengaruh formula crispy cookies pada taraf ke-i terhadap peubah respon

$\mathrm{i}=$ Taraf $(\mathrm{i}=$ formula 0 , formula 1 , formula 2, dan formula 3 )

$\mathrm{j}=\operatorname{Ulangan}(\mathrm{j}=1,2)$

cij $=$ Kesalahan penelitian karena pengaruh taraf ke-i peubah respon pada ulangan ke-j

\section{HASIL}

\section{Proses Pembuatan Tepung Pisang Kepok Putih}

Pisang kepok putih yang digunakan pada penelitian ini diperoleh dari Pasar Reni Jaya, Sawangan Depok.
Hasil rendemen yang didapat dari pembuatan tepung pisang kepok putih sebesar 20,09\%. Hasil rendemen dari penelitian ini tidak jauh berbeda dengan penelitian Palupi (2012) yang memperoleh rendemen tepung pisang kepok sebesar 19,58\% dan penelitian Musita (2012) yang memperoleh rendemen tepung pisang kepok sebesar $22,01 \%$.

\section{Proses Pembuatan Tepung Kacang Hijau}

Bahan baku yang digunakan dalam pembuatan tepung kacang hijau adalah kacang hijau kupas yang diperoleh dari Pasar Reni Jaya, Sawangan Depok. Hasil rendemen yang didapat dari pembuatan tepung kacang hijau sebesar 90,5\%. Hasil rendemen dari penelitian ini tidak jauh berbeda dengan penelitian Nurhidajah, et al. (2010) yang memperoleh rendemen tepung kacang hijau sebesar $91,27 \%$.

\section{Analisis Kimia Tepung Pisang Kepok Putih}

Analisis kimia tepung pisang kepok putih diperoleh dari data sekunder berdasarkan penelitian Kusumaningrum dan Rahayu (2018), yang meliputi analisis proksimat (kadar air, abu, protein, lemak, karbohidrat), analisis serat, dan analisis natrium. Analisis kimia tepung kacang hijau per 100 gram dapat dilihat pada Tabel 2. 
Tabel 2.

Komposisi kimia tepung pisang kepok putih

\begin{tabular}{lr}
\hline Komponen & Hasil $^{*}$ \\
\hline Kadar Air (\% bk) & 10,88 \\
Kadar Abu (\%bk) & 3,22 \\
Protein (\%bk) & 3,04 \\
Lemak (\%bk) & 0,00 \\
Karbohidrat (\%bk) & 82,86 \\
Serat (g/100 g) & 15,24 \\
Natrium (mg/100 g) & 0,00 \\
\hline
\end{tabular}

*Kusumaningrum dan Rahayu (2018)

Analisis Kimia Tepung Kacang Hijau

Analisis kimia tepung kacang hijau yang berupa analisis proksimat (kadar air, abu, protein, lemak, karbohidrat), analisis serat, dan analisis natrium. Komposisi kimia tepung kacang hijau per 100 gram dapat dilihat pada Tabel 3.

Tabel 3.

Komposisi kimia tepung kacang hijau

\begin{tabular}{ll}
\hline Komponen & Hasil \\
\hline Kadar Air (\%bk) & 6,89 \\
Kadar Abu (\%bk) & 3,19 \\
Protein (\%bk) & 24,7 \\
Lemak (\%bk) & 1,97 \\
Karbohidrat (\%bk) & 63,3 \\
Serat (g/100 g) & 5,73 \\
Natrium (mg/100 g) & 0,04 \\
\hline
\end{tabular}

Pembuatan Crispy Cookies Tepung Pisang Kepok Putih dan Tepung Kacang Hijau

Produk crispy cookies dalam penelitian ini dibuat dari bahan pangan lokal yaitu tepung pisang kepok putih dan tepung kacang hijau. Bahan tambahan yang digunakan adalah putih telur, kuning telur, gula halus, susu skim, maizena, santan, dan meses. Penelitian pendahuluan dilakukan formulasi perbandingan tepung komposit berbasis tepung pisang kepok putih dan kacang hijau dengan perbandingan $(1: 9),(2: 8),(3: 7)$. Penggunaan tepung terigu $100 \%$ dijadikan sebagai kontrol (pembanding formula crispy cookies terpilih).

\section{Uji Organoleptik Produk Crispy Cookies}

Crispy cookies yang telah selesai dibuat selanjutnya dilakukan penilaian produk. Pada penilaian produk, uji organoleptik dilakukan untuk menentukan crispy cookies terpilih berdasarkan penilaian uji hedonik dan uji mutu hedonik pada atribut aroma, rasa, dan tekstur menggunakan 30 
panelis semi terlatih. Data hasil uji ditampilkan pada Gambar 1 dan hedonik dan uji mutu hedonik Gambar 2.

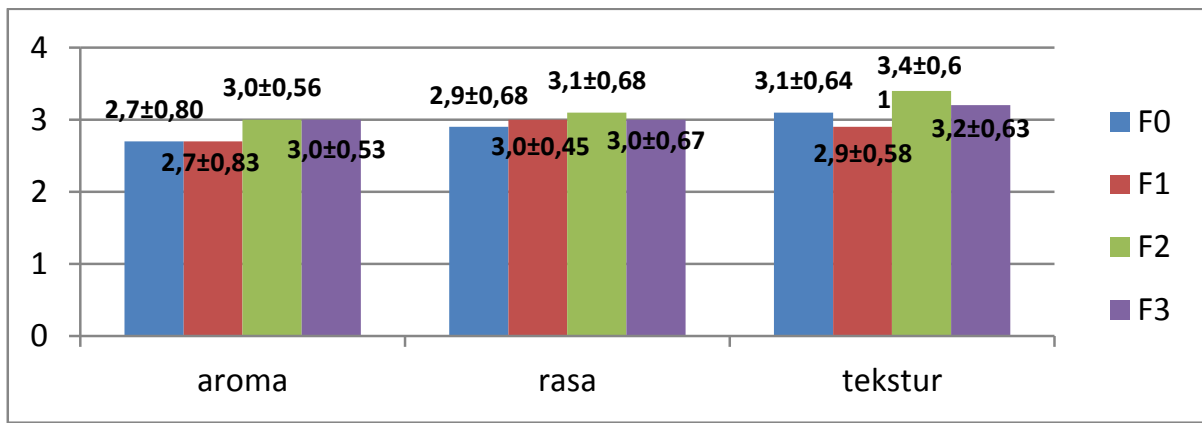

Keterangan:

F0 $=$ Kontrol $(100 \%$ tepung terigu)

F1 $=10 \%$ tepung pisang kepok putih, $90 \%$ tepung kacang hijau

F2 $=20 \%$ tepung pisang kepok putih, $80 \%$ tepung kacang hijau

F3 $=30 \%$ tepung pisang kepok putih, $70 \%$ tepung kacang hijau

Uji hedonik = nilai 4 = sangat suka, $3=$ suka, $2=$ agak suka, $1=$ tidak suka

Gambar 1. Grafik penilaian rata-rata uji hedonik

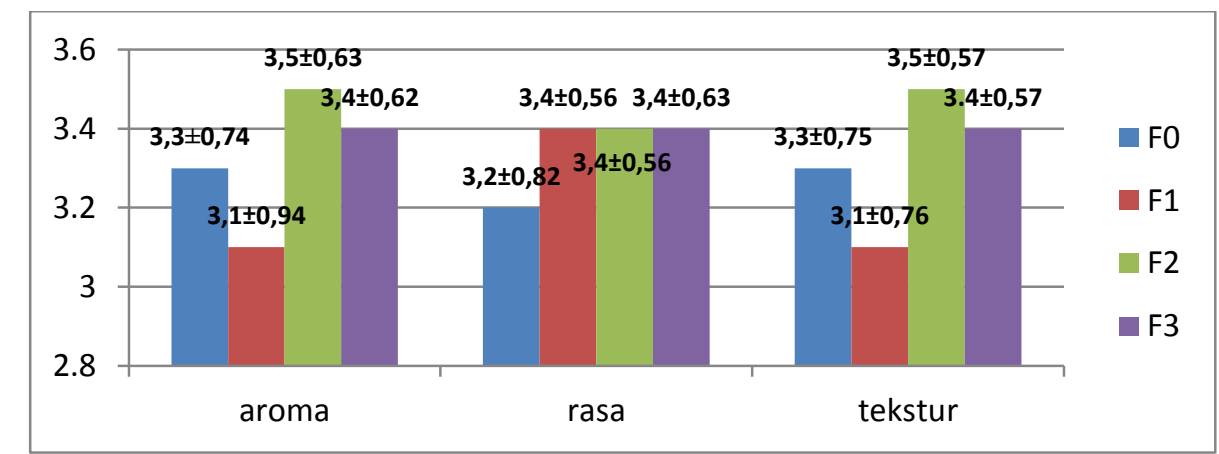

Keterangan:

F0 $=$ Kontrol ( $100 \%$ tepung terigu)

F1 $=10 \%$ tepung pisang kepok putih, $90 \%$ tepung kacang hijau

F2 $=20 \%$ tepung pisang kepok putih, $80 \%$ tepung kacang hijau

F3 $=30 \%$ tepung pisang kepok putih, $70 \%$ tepung kacang hijau

Uji mutu hedonik aroma = nilai $4=$ harum, $3=$ agak harum, $2=$ agak langu, $1=$ langu);

rasa $=$ nilai $4=$ manis, $3=$ agak manis, $2=$ tidak manis, $1=$ sangat tidak manis; tekstur

$=$ nilai $4=$ sangat renyah, $3=$ renyah, $2=$ agak renyah, $1=$ tidak renyah

\section{Gambar 2. Grafik penilaian rata-rata uji mutu hedonik}

\section{Aroma}

Berdasarkan hasil penilaian tingkat kesukaan (hedonik), skor tertinggi pada atribut aroma crispy cookies diberikan oleh panelis pada crispy cookies F2 dan F3 $(3,0)$, yaitu suka. Pada hasil penilaian mutu hedonik, skor tertinggi pada atribut mutu aroma crispy 
cookies diberikan oleh panelis pada crispy cookies F2 $(3,5)$, yaitu antara agak harum dan harum.

Hasil uji ANOVA terhadap penilaian tingkat kesukaan (hedonik) menunjukkan bahwa penggunaan tepung pisang kepok putih dan tepung kacang hijau tidak memiliki pengaruh yang nyata $(p>0,05)$ terhadap aroma crispy cookies. Begitu pula pada penilaian mutu hedonik yang menunjukkan bahwa penggu-naan tepung pisang kepok putih dan tepung kacang hijau tidak memiliki pengaruh yang nyata $(p>0,05)$ terhadap mutu aroma crispy cookies.

Berdasarkan penilaian mutu hedonik secara keseluruhan, penggunaan tepung pisang kepok putih dan tepung kacang hijau pada pembuatan crispy cookies memiliki aroma antara agak harum dan harum (3,1-3,5). Pisang cenderung memiliki aroma khas yang cukup tajam, namun pemilihan jenis pisang kepok putih dengan karakteristik mengkal memiliki aroma pisang yang tidak terlalu menusuk dan cenderung menyerupai tepung terigu (Lesmana dan Utari, 2013). Menurut Pertiwi, et al. (2018) aroma langu yang ditimbulkan oleh kacang hijau karena adanya enzim lipoksigenase dapat diinaktifkan dengan proses penyangraian saat pembuatan tepung dan pengovenan saat pembuatan crispy cookies sehingga muncul aroma kacang hijau yang khas.

Hasil penilaian mutu hedonik yang menunjukkan formula 2 memiliki skor yang lebih tinggi dibandingkan dengan formula kontrol memberi kesimpulan bahwa penggunaan tepung pisang kepok putih sebanyak $20 \%$ dan kacang hijau sebanyak $80 \%$ dalam pembuatan crispy cookies memiliki aroma yang lebih harum dibandingkan dengan penggunaan tepung terigu. Berdasarkan penilaian tingkat kesukaan (hedonik) yang menunjukkan formula 2 dan 3 memiliki skor yang lebih tinggi dibandingkan dengan formula kontrol memberi kesimpulan bahwa panelis lebih menyukai aroma crispy cookies dari olahan tepung pisang kepok putih dan tepung kacang hijau dibandingkan dengan tepung terigu. Hal ini menunjukkan bahwa tepung pisang kepok putih dan tepung kacang hijau dapat digunakan sebagai pengganti tepung terigu dalam produk crispy cookies.

\section{Rasa}

Berdasarkan hasil penilaian tingkat kesukaan (hedonik), skor tertinggi pada atribut rasa crispy cookies diberikan oleh panelis pada crispy cookies F2 $(3,1)$, yaitu antara suka dan sangat suka. Pada hasil penilaian mutu hedonik, skor tertinggi pada atribut mutu rasa crispy cookies diberikan oleh panelis pada crispy cookies F1, F2, dan F3 $(3,4)$, yaitu antara agak manis dan manis.

Hasil uji ANOVA terhadap penilaian tingkat kesukaan (hedonik) menunjukkan bahwa penggunaan tepung pisang kepok putih dan tepung kacang hijau tidak memiliki pengaruh yang nyata $(p>0,05)$ terhadap rasa crispy cookies. Begitu pula pada penilaian mutu hedonik yang menunjukkan bahwa penggunaan tepung pisang kepok putih dan tepung kacang hijau tidak memiliki 
pengaruh yang nyata $(p>0,05)$ terhadap mutu rasa crispy cookies.

Berdasarkan penilaian mutu hedonik secara keseluruhan, penggunaan tepung pisang kepok putih dan tepung kacang hijau pada pembuatan crispy cookies memiliki rasa mendekati manis $(3,4)$ meskipun telah dilakukan modifikasi pengurangan gula. Menurut Sidabutar, et al., (2013) dalam Pertiwi et al., (2018) rasa bahan pangan berasal dari bahan itu sendiri dan apabila telah melalui proses pengolahan maka rasanya akan dipengaruhi oleh bahan yang ditambahkan selama proses pengolahan. Penggunaan meses sebagai topping pada crispy cookies dapat membantu memberikan rasa manis dalam pembuatan crispy cookies tepung pisang kepok putih dan tepung kacang hijau.

Hasil penilaian mutu hedonik yang menunjukkan formula 1 dan 2 memiliki skor yang lebih tinggi dibandingkan dengan formula kontrol memberi kesimpulan bahwa penggunaan tepung pisang kepok putih sebanyak $10-20 \%$ dan kacang hijau sebanyak $80-90 \%$ dalam pembuatan crispy cookies memiliki rasa yang lebih manis dibandingkan dengan penggunaan tepung terigu. Hal ini karena tepung kacang hijau cenderung memiliki rasa yang lebih manis dibandingkan dengan tepung terigu. Berdasarkan penilaian tingkat kesukaan (hedonik) yang menunjukkan formula 2 memiliki skor yang lebih tinggi dibandingkan dengan formula kontrol memberi kesimpulan bahwa panelis lebih menyukai rasa crispy cookies dari olahan tepung pisang kepok putih dan tepung kacang hijau dibandingkan dengan tepung terigu. Hal ini menunjukkan bahwa tepung pisang kepok putih dan tepung kacang hijau dapat digunakan sebagai pengganti tepung terigu dalam produk crispy cookies.

\section{Tekstur}

Berdasarkan hasil penilaian tingkat kesukaan (hedonik), skor tertinggi pada atribut tekstur crispy cookies diberikan oleh panelis pada crispy cookies F2 $(3,4)$, yaitu antara suka dan sangat suka. Pada hasil penilaian mutu hedonik, skor tertinggi pada atribut mutu tekstur crispy cookies diberikan oleh panelis pada crispy cookies F2 dan F3 $(3,5)$, yaitu antara renyah dan sangat renyah.

Hasil uji ANOVA terhadap penilaian mutu hedonik yang menunjukkan bahwa penggunaan tepung pisang kepok putih dan tepung kacang hijau tidak memiliki pengaruh yang nyata (p-value $>0,05)$ terhadap mutu tekstur crispy cookies, sedangkan pada penilaian tingkat kesukaan (hedonik) menunjukkan bahwa penggunaan tepung pisang kepok putih dan tepung kacang hijau memiliki pengaruh yang nyata (p-value $<0,05$ ) terhadap rasa crispy cookies. Uji lanjut Duncan menunjukkan bahwa adanya perbedaan yang nyata antara formula kontrol dan formula 1 dengan formula 2, sedangkan pada formula 3 tidak ada perbedaan yang nyata dengan formula 2 . 
Hasil penilaian mutu hedonik yang menunjukkan formula 2 dan 3 memiliki skor yang lebih tinggi dibandingkan dengan formula kontrol memberi kesimpulan bahwa penggunaan tepung pisang kepok putih sebanyak 20-30\% dan kacang hijau sebanyak $70-80 \%$ dalam pembuatan crispy cookies memiliki tekstur yang lebih renyah dibandingkan dengan penggunaan tepung terigu. Berdasarkan penilaian tingkat kesukaan (hedonik) yang menunjukkan formula 2 memiliki skor yang lebih tinggi dibandingkan dengan formula kontrol memberi kesimpulan bahwa panelis lebih menyukai tekstur crispy cookies dari olahan tepung pisang kepok putih dan tepung kacang hijau dibandingkan dengan tepung terigu. Hal ini menunjukkan bahwa tepung pisang kepok putih dan tepung kacang hijau dapat digunakan sebagai pengganti tepung terigu dalam produk crispy cookies.

\section{Penentuan Formulasi Terpilih}

Berdasarkan hasil penilaian uji kesukaan (hedonik) dan mutu hedonik yang ditampilkan pada Tabel. 4 diperoleh bahwa crispy cookies F2 memiliki skor paling tinggi pada atribut aroma, rasa, dan tekstur sehingga secara keseluruhan uji organoleptik, crispy cookies F2 merupakan produk terpilih yang selanjutnya dilakukan analisis proksimat, kadar serat, dan natrium.

Tabel 4.

Penentuan formulasi terpilih

\begin{tabular}{lccccccccc}
\hline \multirow{2}{*}{ Penilaian } & \multicolumn{3}{c}{ F0 } & \multicolumn{2}{c}{ F1 } & \multicolumn{2}{c}{ F2 } & \multicolumn{2}{c}{ F3 } \\
\cline { 2 - 10 } & Kesukaan & Mutu & Kesukaan & Mutu & Kesukaan & Mutu & Kesukaan & Mutu \\
\hline Aroma & 2,7 & 3,3 & 2,7 & 3,1 & 3,0 & 3,5 & 3,0 & 3,4 \\
Rasa & 2,9 & 3,2 & 3,0 & 3,4 & 3,1 & 3,4 & 3,0 & 3,4 \\
Tekstur & 3,1 & 3,3 & 2,9 & 3,1 & 3,4 & 3,5 & 3,2 & 3,4 \\
\hline Rata-rata & 2,9 & 3,3 & 2,9 & 3,2 & 3,2 & 3,5 & 3,1 & 3,4 \\
\hline
\end{tabular}

\section{DISKUSI}

Pada penelitian ini dihasilkan crispy cookies dengan bahan dasar tepung pisang kepok putih dan tepung kacang hijau. Tepung pisang kepok putih mengandung kadar air 10,88\%, kadar abu 3,22\%, protein 3,04\%, lemak $0 \%$, karbohidrat $82,86 \%$, serat pangan 15,24 $\mathrm{g} / 100 \mathrm{~g}$, dan natrium $0 \mathrm{mg} / 100 \mathrm{~g}$. Tepung kacang hijau mengandung kadar air 6,89\%, kadar abu 3,19\%, protein
$24,7 \%$, lemak 1,97\%, karbohidrat 63,3\%, serat pangan 5,73 g/100 g, dan natrium 0,04 mg/100 g. Crispy cookies tepung pisang kepok putih dan tepung kacang hijau terpilih (F2) dalam 100 gram mengandung kalori sebesar 401,76 kkal. Kandungan serat dan natrium sebesar $6,82 \mathrm{~g}$ dan $137,7 \mathrm{mg}$ sehingga produk ini dapat dijadikan sebagai alternatif makanan selingan bagi penderita 
hipertensi. Hasil analisis kimia crispy cookies terpilih ditampilkan pada Tabel 5.

Crispy cookies tepung pisang kepok putih dan tepung kacang hijau dapat dijadikan sebagai makanan selingan dengan syarat memenuhi $10-15 \%$ kebutuhan energi. Hal ini mengacu pada Peraturan BPOM RI No. 9 Tahun 2016 tentang Acuan Label Gizi untuk umum, kebutuhan energi $2.150 \mathrm{kkal}$, protein 60 gram, lemak 67 gram, karbohidrat 324 gram, serat pangan 30 gram, dan natrium $1500 \mathrm{mg}$. Maka dari itu, saran penyajian produk crispy cookies adalah mengonsumsi 12 keping (60 gram) untuk dua kali selingan karena dapat memenuhi kebutuhan energi sebesar 11\% (241 kkal), kebutuhan protein sebesar 18\% (11 gram), kebutuhan karbohidrat sebesar 11\% (37 gram), kebutuhan lemak sebesar 9\% (6 gram), kebutuhan serat 13\% (4 gram), dan kebutuhan natrium sebesar $6 \% \quad(83$ gram).

Crispy cookies yang dihasilkan dalam percobaan ini dapat diklaim sumber serat, tetapi belum dapat dikatakan sebagai snack rendah natrium. Hal ini mengacu pada peraturan kepala BPOM_RI No. 13 tahun 2016 tentang pengawasan klaim pada label dan iklan pangan olahan karena kandungan serat pangan pada crispy cookies sebesar $6,82 \mathrm{~g}$ per 100 gram melebihi standar klaim sumber serat yaitu $\geq 3$ gram per 100 gram, sedangkan untuk kandungan natrium pada crispy cookies sebesar $137,7 \mathrm{mg}$ per 100 gram melebihi standar klaim rendah natrium yaitu $\leq 120 \mathrm{mg}$. Berdasarkan anjuran makan Dietary Approach to Stop Hypertension (DASH), penderita hipertensi dapat mengonsumsi natrium maksimal $2300 \mathrm{mg}$ per hari dengan asupan natrium dari makanan selingan (10-15\%) maksimal 345 mg. Sebagai produk makanan selingan, anjuran mengonsumsi 12 keping (60 gram) crispy cookies tepung pisang kepok putih dan tepung kacang hijau hanya mengandung $83 \mathrm{mg}$ natrium sehingga aman untuk dikonsumsi penderita hipertensi karena kandungan natrium berada di bawah batas maksimal anjuran Dietary Approach to Stop Hypertension (DASH).

Tabel 5.

$\underline{\text { Hasil analisis kimia crispy cookies terpilih per } 100 \text { gram }}$

\begin{tabular}{lc}
\hline Komponen & Hasil \\
\hline Kadar Air (\%) & 7,06 \\
Kadar Abu (\%) & 4,05 \\
Protein (\%) & 18,66 \\
Lemak (\%) & 9,24 \\
Karbohidrat (\%) & 60,99 \\
Serat (g/100 g) & 6,82 \\
Natrium (mg/ 100 g) & 137,7 \\
Energi (kkal) & 401,76 \\
\hline
\end{tabular}




\section{SIMPULAN}

Crispy cookies yang paling disukai berdasarkan uji hedonik dan mutu hedonik adalah formula 2 (perbandingan tepung pisang kepok putih dan tepung kacang hijau 2:8). Selain itu, hasil penilaian uji organoleptik menunjukkan bahwa tepung pisang kepok putih dan tepung kacang hijau dapat diterima sebagai pengganti tepung terigu dalam produk crispy cookies.

Crispy cookies tepung pisang kepok putih dan tepung kacang hijau dapat dijadikan sebagai alternatif makanan selingan bagi penderita hipertensi karena memenuhi syarat sebagai pangan sumber serat dan kandungan natrium dalam anjuran mengonsumsi produk crispy cookies berada di bawah batas maksimal anjuran Dietary Approach to Stop Hypertension (DASH). Akan tetapi, produk crispy cookies tepung pisang kepok putih dan tepung kacang hijau ini belum mencapai klaim rendah serat sehingga perlu dilakukan optimasi formulasi crispy cookies untuk mencapai klaim rendah serat.

\section{DAFTAR RUJUKAN}

Kemenkes RI. (2018). Tabel Komposisi Pangan Indonesia, 2017. Jakarta: Direktorat Jenderal Kesehatan Masyarakat.

Kemenkes RI. (2019). Laporan Riset Kesehatan Dasar (Riskesdas) Tahun 2018. Jakarta: Balitbangkes.

Kementan RI. (2018). Statistik Pertanian. Pusat Data dan Sistem Informasi Pertanian.
Kusuma, A., Nugroho, SD., \& Parsudi, S. (2017). Selera konsumen dalam pembelian "almond crispy" di Toko Wisata Rasa Jemursari Surabaya. Berkala Ilmiah Agribisnis AGRIDEVINA, 6(1): 13-25.

Kusumaningrum, I. \& Rahayu, N.S. (2018). Formulasi snack bar tinggi kalium dan tinggi serat berbahan dasar rumput laut, pisang kepok dan mocaf sebagai snack alternatif bagi penderita hipertensi. Jurnal ARGIPA, 3(2): 102-110.

Lesmana, D. dan Utari D.M. (2015). Analisis zat gizi dan uji hedonik cookies untuk hipertensi pada pria dan wanita usia dewasa di Kota Bandung tahun 2013. Jurnal Kesehatan hal. 1-20

Musita, N. (2012). Kajian kandungan dan karakteristiknya pati resisten dari berbagai varietas pisang. Jurnal Dinamika Penelitian Industri, 23 (1): 57-65.

Nurhidajah, Waysima, \& Wulandari, N. (2010). Kajian Teknologi Pembuatan Tepung Kacang Hijau Instan Dan Sifat Fisik. Jurnal Pangan dan Gizi, 1(1). https:// Doi.Org/10.26714/Jpg.1.1.2010.\% $25 \mathrm{p}$.

Palupi, HT. (2012). Pengaruh jenis pisang dan bahan perendam terhadap karakteristik tepung pisang ( $\mathrm{Musa}$ Spp). Jurnal Teknologi Pangan, 4(1): 102-120.

Patola, EC. \& Dyah, IWH. (2017). Substitusi pisang kepok putih (Musa balbisiana) pada pembuatan tortilla chips pisang. Jurnal Ilmiah UNTAG Semarang, 6(2): 26-43. 
Pertiwi, RP., Larasati, A., \& Hidayati, L. (2018). Pengaruh teknik sangrai dan panggang dalam pembuatan tepung kacang hijau (Phaseolus radiates L.) terhadap mutu katetong. Teknologi dan Kejuruan, 41(1): 89-100.

Sidabutar, WDR., Nainggolan, R.J., \& Ridwansyah. (2013). Kajian penambahan tepung talas dan tepung kacang hijau terhadap mutu cookies. Di dalam Pertiwi, RP., Larasati, A., \& Hidayati, L. (2018). Pengaruh teknik sangrai dan panggang dalam pembuatan tepung kacang hijau (Phaseolus radiates L.) terhadap mutu katetong. Teknologi dan Kejuruan, 41(1): 89-100.

Sudarmoko, A. (2015). Sehat Tanpa Hipertensi. Yogyakarta: Cahaya Atma Pusaka.
Sumarni, R., Sampurno, E., \& Aprilia, V. (2015). Konsumsi junk food berhubungan dengan hipertensi pada lansia di Kecamatan Kasihan, Bantul, Yogyakarta. Jurnal Ners dan Kebidanan Indonesia, 3(2): 59-63.

Usman, Y., et al. (2019). Indonesia's sample registration system in 2018: A work in progress. Journal of Population and Social Studies, 27(1): $39-52$.

World Health Organization. (2013a). A Global Brief on Hypertension. Geneva, Switzerland.

World Health Organization. (2013b). High Blood Pressure A Public Health Priority. Geneva, Switzerland.

World Health Organization. (2015). Hypertension Fact Sheet. Departement of Sustainable Development and Healthy Environments. 